\title{
Research on flood destruction forecast of Western Zhejiang rural highway based on BP neural network method
}

\author{
Wang Baofeng* \\ Quzhou University, Quzhou (324000) \\ *Corresponding Email: 909814008@qq.com
}

\begin{abstract}
Keywords: flood destruction, BP neural network, rural highway; side slope
Abstract. Since there exists a very complex nonlinear relation between Western Zhejiang rural highway flood destruction and its influencing factors, this paper chooses 6 main factors influencing the flood destruction. Establish Zhejiang rural highway BP neural network model through MATLAB neural network toolbox; through learning a large number of survey data and combining practical examples, based on BP neural network model for the flood destruction forecast of Western Zhejiang rural highway, the forecast on Western Zhejiang rural highway flood destruction is feasible, and plays important role in exploring the flood destruction forecast of Western Zhejiang rural highway.
\end{abstract}

\section{Introduction}

The flood destruction is the damage phenomenon and process of various engineering structures and facilities along the highway after suffering storm, flood erosion, water soaked and other water effect [1]. Western Zhejiang is situated in the western part of Jinhua-Quzhou basin, while the terrain is mostly hilly and mountainous, which belongs to subtropical monsoon climate zone, with anomaly abundant precipitation in recent years. However, the economy of Western Zhejiang is relatively backward in Zhejiang, and the construction of rural highway is restricted by scanty fund and complex terrain, with relatively weak anti disaster ability, that is why the flood destruction phenomenon of Western Zhejiang rural highway is especially serious during rainy season. Therefore, the forecast against Western Zhejiang rural highway flood destruction is very necessary [2-3].

\section{The establishment of BP neural network model for rural highway flood destruction forecast}

There exists a very complex nonlinear relation between Western Zhejiang rural highway flood destruction and its influencing factors. Making use of BP neural network model to evaluate the rural highway can favorably avoid the interference of human factors and obtain relatively objective and accurate results. Because the performance of neural network nonlinear approximation is very strong, it can clearly exact express the relation between input variables and output variables. The neural network toolbox of application software MATLAB contains many functions, which are used in the analysis and design of BP network, so we can utilize related neural network design and training program of the toolbox according to actual needs [4] .

According to abundant survey data of Western Zhejiang rural highway flood destruction, combined with the research contents of this chapter, considering the importance and easy choice of evaluation index, 6 models including rainfall type, rainfall duration, side slope grade, slope height, cohesive force and friction angle have been chosen as input index, while the flood destruction situation serves as model output indexes. Next, the model algorithm will be further simplified and final prediction will be carried out as well.

The learning process of this model is as follows:

(1) Input rainfall intensity, rainfall duration, slope angle, slope height, cohesive force and internal friction angle by using observational data; 
(2) The design of hidden layer and neurons. A three-layer BP network can complete any mapping from n-dimensional to m-dimensional. The topology structure of BP neural network is 6-10-1.

Table 1 Quantification Result of Flood destruction Level

\begin{tabular}{|c|c|c|}
\hline $\begin{array}{l}\text { Flood destruction Amount / [g/ } \\
\left.\mathrm{m}^{2}\right]\end{array}$ & Flood destruction Level & Quantification Result \\
\hline$<20$ & Without & 1 \\
\hline $20 \sim 30$ & Slight & 2 \\
\hline $30 \sim 70$ & Medium & 3 \\
\hline $70 \sim 130$ & Serious & 4 \\
\hline$>130$ & Extremely Serious & 5 \\
\hline
\end{tabular}

(3) The construction of learning samples and test samples

1) Sample selection

To evaluate the slope stability through neural network, a training sample should be given in advance. Whether the reference of neural network performance and obtained results are objective is closely related with whether selected training samples are right. Usually, the sample selection considers two factors: first, the length of training sample. The sample size is not the longer the better. If the sample size is too large, it will not only affect the calculation speed of the whole neural network, but lead to the decrease of the fitting precision. If the sample size is too small, it may make insufficient expression of the network, which leads to insufficient network extrapolation ability. Second, the representativeness of training samples. Sample selection must be representative, in order to ensure the accuracy of the model evaluation and improve the accuracy of the results. Therefore, the principle of selecting samples: A, adopt typically representative engineering examples; $\mathrm{B}$, avoid data repetitive selection with the same features. The first 35 samples in Table 2 are selected to construct evaluation samples, and the later 5 samples are used as the test sample and applied to the BP neural network model.

Table 2 Samples of flood destruction

\begin{tabular}{|c|c|c|c|c|c|c|c|c|}
\hline NO. & Rainfall grade & $\begin{array}{c}\text { Duration } \\
\text { of rainfall } \\
\text { [day }]\end{array}$ & $\begin{array}{l}\text { Slope } \\
\text { angle }\end{array}$ & $\begin{array}{l}\text { Slope } \\
\text { height } \\
{[\mathrm{m}]}\end{array}$ & $\begin{array}{l}\text { Cohesion } \\
\mathrm{kpa}\end{array}$ & $\begin{array}{l}\text { Friction } \\
\text { angle } \\
{\left[{ }^{\circ}\right]}\end{array}$ & $\begin{array}{l}\text { amount of } \\
\text { damage } \\
{\left[\mathrm{g} / \mathrm{m}^{2}\right]}\end{array}$ & $\begin{array}{l}\text { Flood } \\
\text { destruction } \\
\text { Level }\end{array}$ \\
\hline 1 & Heavy rain & 5 & 46 & 11 & 10 & 30 & 125 & 4 \\
\hline 2 & Rainstorm & 3 & 50 & 20 & 18 & 35 & 140 & 5 \\
\hline 3 & Light rain & 2 & 20 & 8 & 5 & 21 & 15 & 1 \\
\hline 4 & Heavy rain & 1 & 38 & 25 & 18 & 31 & 26 & 2 \\
\hline 5 & Light rain & 3 & 47.8 & 26 & 18.8 & 28 & 10 & 1 \\
\hline
\end{tabular}




\begin{tabular}{|c|c|c|c|c|c|c|c|c|}
\hline NO. & Rainfall grade & $\begin{array}{c}\text { Duration } \\
\text { of rainfall } \\
\text { [day] }\end{array}$ & $\begin{array}{l}\text { Slope } \\
\text { angle }^{\circ}\end{array}$ & $\begin{array}{l}\text { Slope } \\
\text { height } \\
\text { [m] }\end{array}$ & $\begin{array}{l}\text { Cohesion } \\
\text { kpa }\end{array}$ & $\begin{array}{l}\text { Friction } \\
\text { angle } \\
{\left[{ }^{\circ}\right]}\end{array}$ & $\begin{array}{l}\text { amount of } \\
\text { damage } \\
{\left[\mathrm{g} / \mathrm{m}^{2}\right]}\end{array}$ & $\begin{array}{l}\text { Flood } \\
\text { destruction } \\
\text { Level }\end{array}$ \\
\hline 6 & Rainstorm & 1 & 48 & 30 & 26 & 5 & 65 & 3 \\
\hline 7 & Moderate rain & 4 & 40 & 31 & 10 & 37.8 & 29 & 2 \\
\hline 8 & Light rain & 11 & 42 & 28 & 35 & 40 & 24 & 2 \\
\hline 9 & Heavy rain & 1 & 33 & 8 & 5 & 40 & 16 & 1 \\
\hline 10 & Moderate rain & 5 & 23 & 18 & 5 & 30 & 17 & 1 \\
\hline 11 & Moderate rain & 3 & 40 & 30 & 45 & 40 & 23 & 2 \\
\hline 12 & Rainstorm & 4 & 45 & 32 & 5 & 26 & 200 & 5 \\
\hline 13 & Rainstorm & 3 & 38 & 13 & 6.6 & 22 & 127 & 4 \\
\hline 14 & Heavy rain & 2 & 46 & 35 & 44 & 36 & 24 & 2 \\
\hline 15 & Heavy rain & 1 & 40 & 28 & 10 & 40 & 16 & 1 \\
\hline 16 & Heavy rain & 2 & 47 & 25 & 46 & 33 & 28 & 2 \\
\hline 17 & Moderate rain & 7 & 42.2 & 27 & 37.5 & 31 & 22 & 2 \\
\hline 18 & Rainstorm & 2 & 41 & 15 & 16.8 & 27.3 & 26 & 2 \\
\hline 19 & Light rain & 9 & 45 & 26 & 9.6 & 30 & 95 & 4 \\
\hline 20 & Moderate rain & 6 & 41 & 30 & 31.5 & 39.7 & 24 & 2 \\
\hline 21 & Rainstorm & 3 & 46 & 36 & 68 & 36 & 66 & 3 \\
\hline 22 & Light rain & 4 & 34.5 & 28 & 55 & 36 & 6 & 1 \\
\hline 23 & Moderate rain & 9 & 47.1 & 35 & 45 & 35 & 22 & 2 \\
\hline 24 & Heavy rain & 2 & 20 & 10 & 5 & 31 & 26 & 2 \\
\hline 25 & Light rain & 14 & 25 & 6 & 25 & 5 & 67 & 3 \\
\hline 26 & Rainstorm & 1 & 40 & 30 & 16 & 39 & 5 & 1 \\
\hline 27 & Moderate rain & 1 & 35 & 4 & 5 & 30 & 4 & 1 \\
\hline 28 & Light rain & 6 & 30 & 26 & 16 & 30.3 & 8 & 1 \\
\hline 29 & Heavy rain & 2 & 37.8 & 27 & 17.5 & 35 & 22 & 2 \\
\hline 30 & Rainstorm & 1 & 42.6 & 20 & 12 & 33 & 57 & 3 \\
\hline
\end{tabular}




\begin{tabular}{|c|c|c|c|c|c|c|c|c|}
\hline NO. & Rainfall grade & $\begin{array}{c}\text { Duration } \\
\text { of rainfall } \\
\text { [day] }\end{array}$ & $\begin{array}{l}\text { Slope } \\
\text { angle }^{\circ}\end{array}$ & $\begin{array}{l}\text { Slope } \\
\text { height } \\
\text { [m] }\end{array}$ & $\begin{array}{l}\text { Cohesion } \\
\text { kpa }\end{array}$ & $\begin{array}{l}\text { Friction } \\
\text { angle } \\
{\left[{ }^{\circ}\right]}\end{array}$ & $\begin{array}{l}\text { amount of } \\
\text { damage } \\
{\left[\mathrm{g} / \mathrm{m}^{2}\right]}\end{array}$ & $\begin{array}{l}\text { Flood } \\
\text { destruction } \\
\text { Level }\end{array}$ \\
\hline 31 & Rainstorm & 3 & 45 & 23 & 12 & 33 & 28 & 2 \\
\hline 32 & Rainstorm & 1 & 49 & 31 & 68 & 37 & 23 & 2 \\
\hline 33 & Heavy rain & 1 & 33 & 8 & 5 & 40 & 6 & 1 \\
\hline 34 & Light rain & 10 & 50 & 27 & 26 & 31 & 27 & 2 \\
\hline 35 & Rainstorm & 1 & 42.6 & 32 & 37.5 & 36 & 20 & 2 \\
\hline 36 & Heavy rain & 2 & 22.2 & 33 & 40 & 45 & 25 & 2 \\
\hline 37 & Moderate rain & 7 & 36 & 35 & 26 & 25 & 27 & 2 \\
\hline 38 & Rainstorm & 3 & 45 & 20 & 20 & 36 & 112 & 4 \\
\hline 39 & Heavy rain & 7 & 50 & 15.3 & 18.1 & 21.28 & 300 & 5 \\
\hline 40 & Heavy rain & 2 & 40 & 55 & 27.5 & 20 & 24 & 2 \\
\hline
\end{tabular}

3) Use data normalization to process the accuracy of network model; prevent small numerical information from being submerged by large numerical information; accelerate the convergence speed of training network. The sample data needs normalization processing, so as to make larger input fall into the site of large gradient in neural transferring function.

$$
x^{\prime}=\frac{x^{\prime}-x_{\min }}{x_{\max }-x_{\min }}
$$

Normalization processing.

\section{4) Flood destruction model forecast}

Based on the established BP model, utilize learning samples to train the network, MATLAB will obtain BP neural network slope stability evaluation training with using Traningdm algorithm. After training 1460 times, the network error will meet requirement, with training accuracy of 0.0008 . The forecast safety coefficient of BP neural network model for evaluating slope stability is obtained by software MATLAB, see in table 1.3.

Table 1.3 shows, through carrying out neural network training on learning samples, and comparing actual flood destruction amount and forecast flood destruction amount, 4 samples is judged to be error in 35 samples, the accuracy rate of BP neural network flood destruction amount determination is $88.5 \%$.

5)Checkout

After carrying out normalization processing on the selected No. 36 to No.40 test samples from Table 1.2, input BP neural network flood destruction forecast model to get training results, which are given in Table 1.4

From the above table, we can see that the results are consistent with the actual situation, which means when BP neural network forecast model is applied to forecast Western Zhejiang rural highway flood destruction, it basically meets the precision requirements of application, with high reliability and 
applicability.

Table 1. 3 Comparison table for the actual flood destruction amount and BP forecast flood destruction amount of Learning samples

\begin{tabular}{|l|l|l|l|l|l|l|l|l|l|l|l|l|}
\hline N0. & 1 & 2 & 3 & 4 & 5 & 6 & 7 & 8 & 9 & 10 & 11 & 12 \\
\hline Actual amount & 125 & 140 & 15 & 26 & 10 & 65 & 29 & 24 & 16 & 17 & 23 & 200 \\
\hline Forecast amount & 128 & 145 & 18 & 25 & 12 & 66 & 32 & 28 & 15 & 15 & 26 & 220 \\
\hline N0. & 13 & 14 & 15 & 16 & 17 & 18 & 19 & 20 & 21 & 22 & 23 & 24 \\
\hline Actual amount & 127 & 24 & 16 & 28 & 22 & 26 & 95 & 24 & 66 & 6 & 22 & 26 \\
\hline Forecast amount & 135 & 26 & 15 & 29 & 20 & 29 & 106 & 23 & 76 & 8 & 21 & 26 \\
\hline N0. & 25 & 26 & 27 & 28 & 29 & 30 & 31 & 32 & 33 & 34 & 35 & \\
\hline Actual amount & 67 & 5 & 4 & 8 & 22 & 57 & 28 & 23 & 6 & 27 & 20 & \\
\hline Forecast amount & 61 & 6 & 5 & 9 & 26 & 54 & 23 & 24 & 5 & 35 & 19 & \\
\hline
\end{tabular}

Table 1.4 Comparison table for the actual flood destruction amount and forecast flood destruction amount of test samples

\begin{tabular}{|l|c|c|c|c|c|}
\hline No. & 36 & 37 & 38 & 39 & 40 \\
\hline Actual amount & 25 & 27 & 112 & 300 & 24 \\
\hline Forecast amount & 26 & 25 & 117 & 290 & 28 \\
\hline
\end{tabular}

\section{Western Zhejiang rural highway application}

According to rainfall, time, slope angle, slope height, cohesive force, friction angle of part highway slope in Hunan Town, Qujiang District, Quzhou city, collected by BP neural network flood destruction forecast model, adopt above BP neural network forecast result 2, which belongs to slight flood destruction and conforms with actual situation in Picture 2.1.

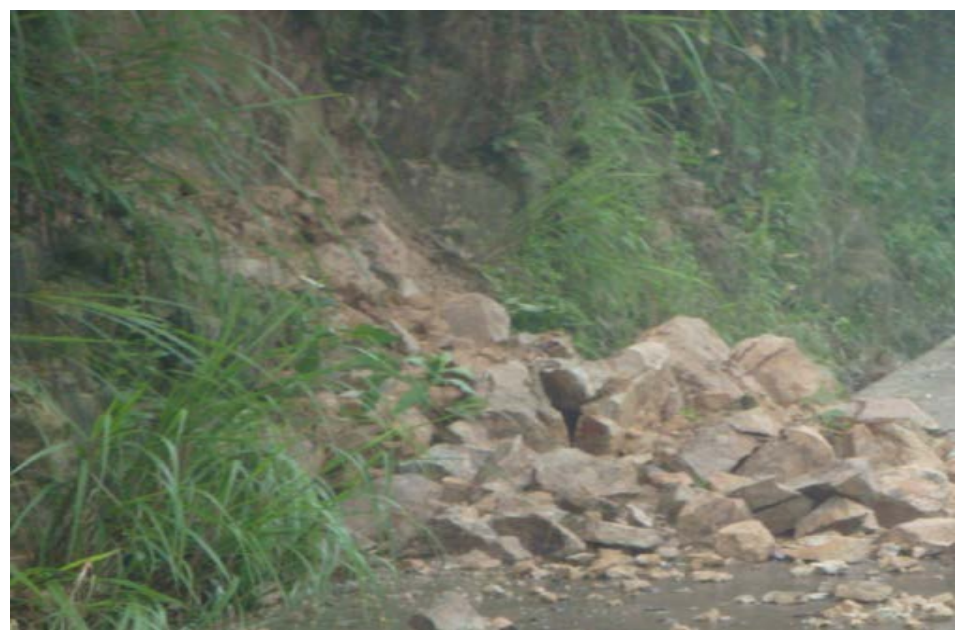

Figure 2.2 Highway Flood destruction Condition in Baiwukou Village 
From this, it is determined that the results are consistent with actual situation, which means BP neural network flood destruction forecast model prediction model is effective when it is used to forecast Western Zhejiang rural highway flood destruction and can be applied to flood destruction prevention in rural highway.

\section{Conclusion}

1) Establish BP neural network flood destruction forecast model to predict flood destruction in Western Zhejiang rural highway is feasible.

2) The model chooses 6 main influence factors including rainfall types, rainfall duration, slope gradient, slope height, cohesive force and friction angle as the model input index is consistent with actuality, which will simplify the rainfall capacity into rainfall type to meet the accuracy requirements.

3) Vast actual flood destruction data is the foundation for establishing flood destruction model, which plays important role in building rural highway flood destruction database in different Western Zhejiang areas, to provide a reliable basis for flood destruction forecast.

\section{Acknowledgements}

This work was supported by Science and technology project of Quzhou (Item number :2013Y014), and Funding program of Quzhou University (Item number : KY1312)

\section{References}

[1] Zhejiang Highway Administration Bureau,Highway Flood destruction Prevention and Treatment, China Communications Press.,Beijing,2000

[2] Gong Xinfa,Current Characteristics and Causes of Debris Flow in the Northern Mountainous, Zhejiang Land and Resources.,Area of Yueqing City, 2004 ,pp. 36-140.

[3] Qi Guoli, Zou Changlai,Highway Disease and Disease Management. The forest engineering.,2001,pp. 62-63

[4] Gao Dongguang, Highway and Flood destruction Bridge Prevention and Treatment Beijing: China Communications Press., 2002

[5] Li Hairui, Discussion on Prevention and Treatment for Mountainous Highway Flood destruction , Highway, 1995 ,pp. 37-39.

[6] Chen Gang, Wang Yongyue, Yang Xunping. Flood destruction Cause and Repair Method for Culvert., 2006 ,pp. 450

[7] Cheng Qingzhan,Study on Geological Hazard Type and Evaluation Division in Fujian Province. Master's degree thesis of Fujian Normal University., 2000.

[8] Cong Shuang,Neural Network Theory And Application of Matlab Toolbox, China Science and Technology Press.,Hefei, 1998 